\title{
THE EFFECT OF TOLUENE SOLUTION ON THE HYDROGEN ABSORPTION OF THE Mg-Ti ALLOY PREPARED BY SYNTHETIC ALLOYING
}

\author{
H. Suwarno ${ }^{1 *}$ and W.A. Adi ${ }^{2}$ \\ ${ }^{1}$ Center for Nuclear Fuel Technology, BATAN \\ Kawasan Puspiptek, Serpong, Tangerang 15314, Banten, Indonesia \\ ${ }^{2}$ Center for Nuclear Industry Materials Technology, BATAN \\ Kawasan Puspiptek, Serpong, Tangerang 15314, Banten, Indonesia \\ Received 27 January 2009; Received in revised form 19 November 2009; Accepted 24 November 2009
}

\begin{abstract}
THE EFFECT OF TOLUENE SOLUTION ON THE HYDROGEN ABSORPTION OF THE Mg-Ti ALLOY PREPARED BY SYNTHETIC ALLOYING. The synthesis and characterization of the $\mathrm{Mg}-\mathrm{Ti}$ alloy have been carried out through a mechanical alloying technique under toluene solution. The $\mathrm{Mg}$ and $\mathrm{Ti}$ powders are milled for 10, 20, and $30 \mathrm{~h}$ in a high energy ball mill. The milled alloys are then hydrided at a temperature of $300{ }^{\circ} \mathrm{C}$ in order to investigate the possibility used for hydrogen storage materials. The refinement analyses of the $\mathrm{x}$-ray diffraction patterns show that mechanical alloying of the $\mathrm{Mg}$ - $\mathrm{Ti}$ powders under toluene solution results in the formation of the $\mathrm{TiH}_{2}$ and $\mathrm{Mg}_{2} \mathrm{Ti}$ phases. Quantitative analyses indicate that the mass fractions of the $\mathrm{TiH}_{2}$ and $\mathrm{Mg}_{2} \mathrm{Ti}$ phases are $62.90 \%$ and $30.60 \%$, while the value for $\mathrm{Mg}$ and $\mathrm{Ti}$ amount to $2.6 \mathrm{wt} \%$ and $1.25 \mathrm{wt} \%$. On hydriding at a temperature of $300{ }^{\circ} \mathrm{C}$, the milled powders are transformed into $\mathrm{Mg}_{2} \mathrm{TiH}_{4}, \mathrm{TiH}_{2}$ and $\gamma-\mathrm{MgH}_{2}$ phases with the mass fractions of $25.48 \mathrm{wt} \%, 64.0 \mathrm{wt} \%$, and $10.52 \mathrm{wt} \%$, respectively. Microstructure analyses show that before milling the shape of particle is mostly a ball shape, after $30 \mathrm{~h}$ of milling the shape of particles changes into polygonal shape, and upon hydriding the shape of particles changes from a polygonal shape into an irregular one. The final composition of the specimen after hydriding exhibits that Mg$\mathrm{Ti}$ alloy can be promoted as a hydrogen storage material.
\end{abstract}

Keywords: metal hydride, Mg-Ti system, mechanical alloying, hydriding

() 2009 Atom Indonesia. All rights reserved.

\section{INTRODUCTION}

In the future fuel technology for transportation will be based on hydrogen as an effort to protect the earth from greenhouse gas (GHG) emissions. An effective and cheap storage system is crucial for the utilization of hydrogen as a pollution-free energy carrier. A number of storage methods are being developed, one of which is storing hydrogen in the form of metal hydrides. Metal hydrides are used as reversible solid-state hydrogen storage at low pressures with high volumetric capacity, i.e. it should contain several $\mathrm{kg}$ of metal hydride powder. Magnesium has undergone many years

\footnotetext{
Corresponding author.

E-mail address : hadis@ batan.go.id (H. Suwarno)
} 
of research due to its high hydrogen capacity, absorbing hydrogen up to $7.6 \mathrm{wt} \%$ [1-3].

Synthetic alloying by mechanical ball milling is the most common processing technique for producing nano-particle powders, including synthesizing magnesium based alloys [4-7]. Upon milling, repeated collisions between the balls and the powders will induce mechanical deformations, introduce strain into the powder and, as a result, fracture the crystallites into the nanometer size range. Repeated cold welding and fracture events minimize the diffusion distance between each compound, allowing the formation of alloys with unique chemical, physical and mechanical properties. The process has been successfully applied to the synthesis of various materials such as magnetic, tribologic, superlatic, catalytic and hydrogen storage materials [8]. Thus many advantages can be obtained from working with a high energy mechanical ball milling.

Nanosize particles play an important role in metal hydride materials as smaller particles have greater surface area and therefore greater surface contact between the materials and hydrogen [9]. Referring to the Zaluska's experiment, magnesium powders with a grain size of about $1 \mu \mathrm{m}$ exhibit negligible hydrogen absorption at $300{ }^{\circ} \mathrm{C}$. At the same time, magnesium with a grain size smaller than $1 \mu \mathrm{m}$ shows a remarkable enhancement of hydrogen absorption indicating that the smaller the grain size, the faster the absorption. The fastest absorption was observed for powders with an average grain size of about 20-30 nm wherein about $5 \mathrm{wt} \%$ hydrogen was absorbed in 40 mins. For a grain size around $50 \mathrm{~nm}$, only $3 \mathrm{wt} \%$ was absorbed within the same period [10].

$\mathrm{Mg}$ and $\mathrm{Ti}$ are well known as light weight hydrogen storage materials. Hydrogen can be stored more safely and compactly in these materials than being compressed or transformed into liquid form. The materials are usually covered with thin layers of oxides or hydroxides and require activation treatment under high temperature $\left(>300{ }^{\circ} \mathrm{C}\right)$ and at the hydrogen pressure of $>3 \mathrm{MPa}$ before being used for storage and transport applications [11].

In this research, the wet method mechanical alloying technique, using wet method with toluene as the medium is applied to synthesize the $\mathrm{Mg}$ and Ti powders. The milled powders are then hydrided at a temperature of $300{ }^{\circ} \mathrm{C}$ and the results are analyzed. Details of the experiment are presented in this paper.

\section{EXPERIMENTAL METHODS}

The $\mathrm{Mg}$ and $\mathrm{Ti}$ powders used in the experiment are obtained from Sigma-Aldrich ${ }^{\circledR}$ with a purity of $99.5 \%$ and -325 mesh in size for $\mathrm{Mg}$ and a purity of $99.7 \%$ and -100 mesh in size for Ti. About 15 grams of $\mathrm{Mg}$ and $\mathrm{Ti}$ elements with an atomic ratio of $\mathrm{Mg}: \mathrm{Ti}=2: 1$ are mixed together with milling balls and then poured into a vial together with the toluene. All the preparation 
works are conducted in a glove box under high purity argon atmosphere. The use of toluene solution is to avoid the direct contact of the powders with the oxygen during milling. The ball-to-specimen ratio is 8 , and the milling is performed for 10,20 , and $30 \mathrm{~h}$ in the toluene solution at room temperature. The vial is made of stainless steel with a diameter of $5.1 \mathrm{~cm}$ and $7.6 \mathrm{~cm}$ in length. The balls are also made of stainless steel with a diameter of $12 \mathrm{~mm}$. The vial is then put into a high energy milling (HEM) Spex type 8000. One cycle of milling of the Spex 8000 consists of normal blending speed of $4500 \mathrm{rpm}$, run time of 90 minutes, and off time of 30 minutes. Thus $10 \mathrm{~h}$ of milling corresponds to 5 cycles of milling operation.

The hydriding experiment is conducted in a Sievert's system under high vacuum condition with a maximum operating pressure of 1000 mbar. The procedure of the experiment has been published elsewhere [12].

The microstructures of the specimens are observed in a scanning electron microscope, Philip type 550. The quality and quantity of the phases formed are analyzed using an x-ray diffractometer (XRD), Philip, type PW 1710, with $\mathrm{Cu}$ as the anode tube and $\lambda=1.5406 \AA$. Continuous scanning is conducted at $0.02^{\circ}$ step size and 0.5 second/step. The scanning results are analyzed using Rietveld method developed by Fuji Izumi [13].

\section{RESULT AND DISCUSSION}

Figure 1 shows the XRD refinement result of the Mg-Ti alloy with the atomic ratio of $\mathrm{Mg}: \mathrm{Ti}=2: 1$ before milling. The figure reveals no impurities and only $\mathrm{Mg}$ and Ti phases are identified.

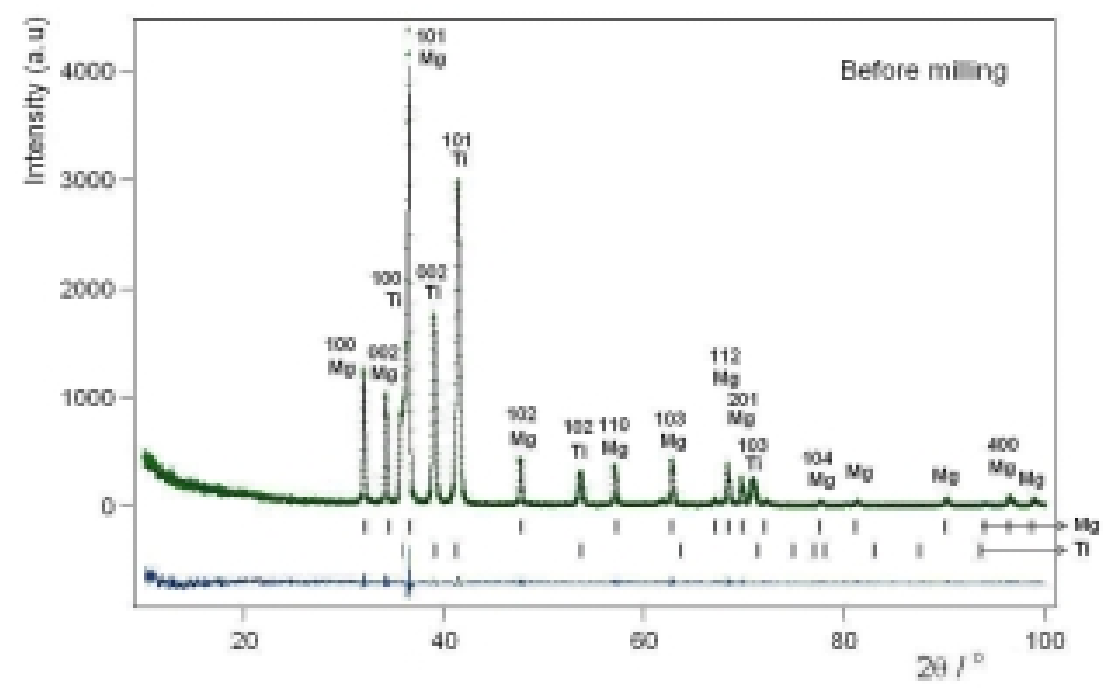

Figure 1. The XRD refinement result of the $\mathrm{Mg}$ and Ti before milling. 
The structure parameters and Wyckoff positions number of equivalent points per unit cell for the $\mathrm{Mg}$ and Ti phases are presented in Table 1.

Table 1. The structure parameters and Wyckoff positions for $\mathrm{Mg}$ and Ti phases.

\begin{tabular}{|c|c|c|c|c|c|c|c|c|c|}
\hline \multicolumn{5}{|c|}{ Mg phase (ref. Swanson [14]) } & \multicolumn{5}{|c|}{ Ti phase (ref. Sailer [15]) } \\
\hline \multicolumn{5}{|c|}{$\begin{array}{l}\text { Space group : } \mathrm{P}_{3} / \mathrm{mmc}(194) \\
\text { Crystal system: hexagonal } \\
\text { Lattice parameters : } \\
a=b=3.223(5) \AA \text {, dan } c=5.249(6) \AA\end{array}$} & \multicolumn{5}{|c|}{$\begin{array}{l}\text { Space group : } \mathrm{P} 6_{3} / \mathrm{mmc}(194) \\
\text { Crystal system : hexagonal } \\
\text { Lattice parameters : } \\
\begin{array}{l}a=b=2.819(1) \AA \text { d dan } c \\
=4.682(2) \AA\end{array}\end{array}$} \\
\hline Atom & Occ & $x$ & $y$ & $z$ & Atom & Occ & $x$ & $y$ & $z$ \\
\hline $\mathrm{Mg}$ & 1.0 & $0.299(1)$ & $0.690(1)$ & 0,25 & $\mathrm{Ti}$ & 1.0 & 0.5 & 0.667 & 0.25 \\
\hline
\end{tabular}

Quantitative analyses of the XRD refinement result yield the mass fractions of $62.76 \mathrm{wt} \%$ and $37.24 \mathrm{wt} \%$ for $\mathrm{Mg}$ and Ti respectively, which are equal to the initial composition of the $\mathrm{Mg}$ and Ti metals.

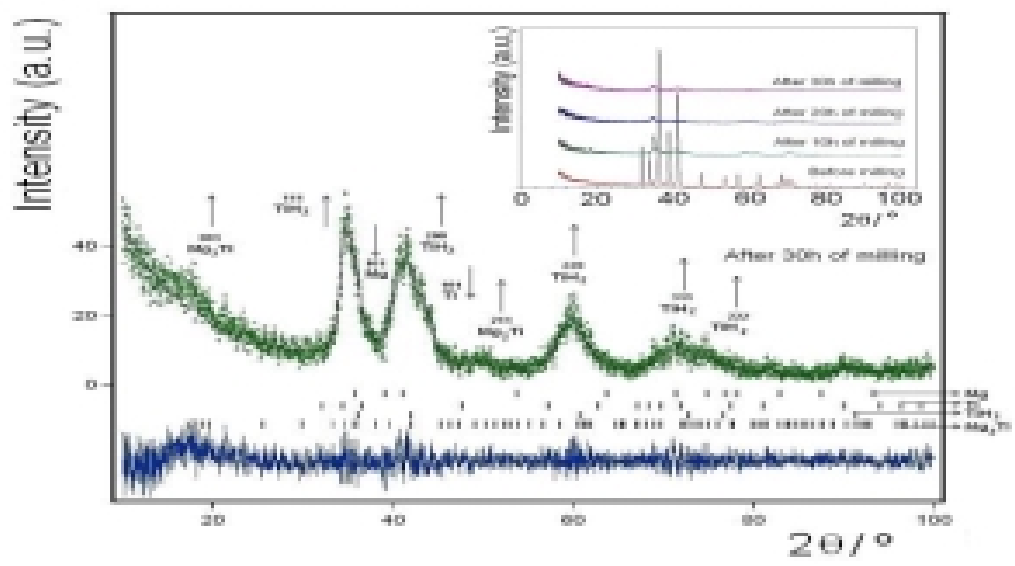

Figure 2. The XRD refinement result of the $\mathrm{Mg}$ and $\mathrm{Ti}$ after $30 \mathrm{~h}$ of milling.

Figure 2 presents the XRD refinement result of the specimen after $30 \mathrm{~h}$ of milling. The peak intensities that belong to $\mathrm{Mg}$ and $\mathrm{Ti}$ almost disappear and only the strongest peaks remain, though at low intensities. The loss of $\mathrm{Mg}$ and $\mathrm{Ti}$ peaks is suggested to be caused by a change in the crystal structure of the specimens into amorphous states and the formation of a new phase. Several new peaks appear at $2 \theta$ close to $19^{\circ}, 35^{\circ}, 40^{\circ}, 45^{\circ}, 59^{\circ}$, and $70^{\circ}$. The refinement result of these peaks allows the identification of the $\mathrm{Mg}, \mathrm{Ti}$, $\mathrm{TiH}_{2}$ and $\mathrm{Mg}_{2} \mathrm{Ti}$ phases. The structure parameters and Wyckoff positions number of equivalent points per unit cell for $\mathrm{TiH}_{2}$ and $\mathrm{Mg}_{2} \mathrm{Ti}$ phases are presented in Table 2. 
Table 2. The structure parameters and Wyckoff positions for $\mathrm{TiH}_{2}$ and $\mathrm{Mg}_{2} \mathrm{Ti}$ phases.

\begin{tabular}{|c|c|c|c|c|c|c|c|c|c|}
\hline \multicolumn{5}{|c|}{$\mathrm{TiH}_{2}$ phase (ref. Crane [16]) } & \multicolumn{5}{|c|}{$\mathrm{Mg}_{2} \mathrm{Ti}$ phase (ref. Soubeyroux [17]) } \\
\hline \multicolumn{5}{|c|}{$\begin{array}{l}\text { Space group : Fm } 3 \mathrm{~m}(225) \\
\text { Crystal structure : cubic } \\
\text { Lattice parameters : } \\
a=b=c=4.330(3) \AA\end{array}$} & \multicolumn{5}{|c|}{$\begin{array}{l}\text { Space group : } \mathrm{P}_{2} 22(180) \\
\text { Crystal structure : hexagonal } \\
\text { Lattice parameters : } \\
a=b=7.542(1) \AA \text {, dan } c=8.516(1) \AA\end{array}$} \\
\hline Atom & Occ & $x$ & $y$ & $z$ & Atom & Occ & $x$ & $y$ & $z$ \\
\hline $\mathrm{Ti}$ & 1.0 & 0.0 & 0.0 & 0.0 & $\mathrm{Ti}$ & 1.0 & 0.333 & 0.667 & $0.063(1)$ \\
\hline \multirow[t]{2}{*}{$\mathrm{H}$} & 1.0 & 0.25 & 0.25 & 0.25 & $\operatorname{Mg}(1)$ & 1.0 & 0.0 & 0.0 & 0.0 \\
\hline & & & & & $\operatorname{Mg}(2)$ & 1.0 & $0.833(1)$ & $0.666(1)$ & 0.25 \\
\hline
\end{tabular}

Quantitative analyses of the XRD refinement result point out that the mass fractions of the $\mathrm{Mg}, \mathrm{Ti}, \mathrm{TiH}_{2}$ and $\mathrm{Mg}_{2} \mathrm{Ti}$ are $5.26 \mathrm{wt} \%, 1.25 \mathrm{wt} \%$, $62.90 \mathrm{wt} \%$ and $30.60 \mathrm{wt} \%$, respectively. The formation of the $\mathrm{TiH}_{2}$ phase is suggested to come from the inter-reaction between $\mathrm{Ti}$ and hydrogen from the toluene $\left(\mathrm{C}_{7} \mathrm{H}_{8}\right)$.

$$
6 \mathrm{Mg}+3 \mathrm{Ti} \stackrel{\text { Toluene }}{\rightarrow} \mathrm{Mg}_{2} \mathrm{Ti}+\mathrm{TiH}_{2}+4 \mathrm{Mg}+\mathrm{Ti}
$$

Eq. (1) indicates that the quantity of $\mathrm{Mg}$ is relatively high. Nevertheless, the calculation indicates that the mass fraction of $\mathrm{Mg}$ is only about $5.26 \mathrm{wt} \%$. Therefore, it is suggested that some of the $\mathrm{Mg}$ particles change into an amorphous state. Figure 2 shows that after $30 \mathrm{~h}$ of milling, intensities of the $\mathrm{TiH}_{2}$ and $\mathrm{Mg}_{2} \mathrm{Ti}$ decline and broaden, an indication that the quantity of $\mathrm{TiH}_{2}$ and $\mathrm{Mg}_{2} \mathrm{Ti}$ crystallites have been reduced.

Figure 3 shows that the peaks of the $\mathrm{TiH}_{2}$ and $\mathrm{Mg}_{2} \mathrm{Ti}$ phases normalize after 10, 20 and $30 \mathrm{~h}$ of milling and for the $\mathrm{TiH}_{2}$ phase the peaks in the (111) plane and (200) plane drastically decline. It is exhibited that the decline of the peaks is resulted from the formation of amorphous states, both for the $\mathrm{Mg}$ and $\mathrm{TiH}_{2}$ phases. From the analysis result, it is also suggested that the formation of the $\mathrm{TiH}_{2}$ disturbs the growth of the $\mathrm{Mg}_{2} \mathrm{Ti}$.

Figure 4 shows the grain sizes of individual crystallites calculated using Scherrer formula. The small size of the particles satisfies the condition for the hydriding process, where the smaller the particle the faster the hydrogen absorption [8]. 

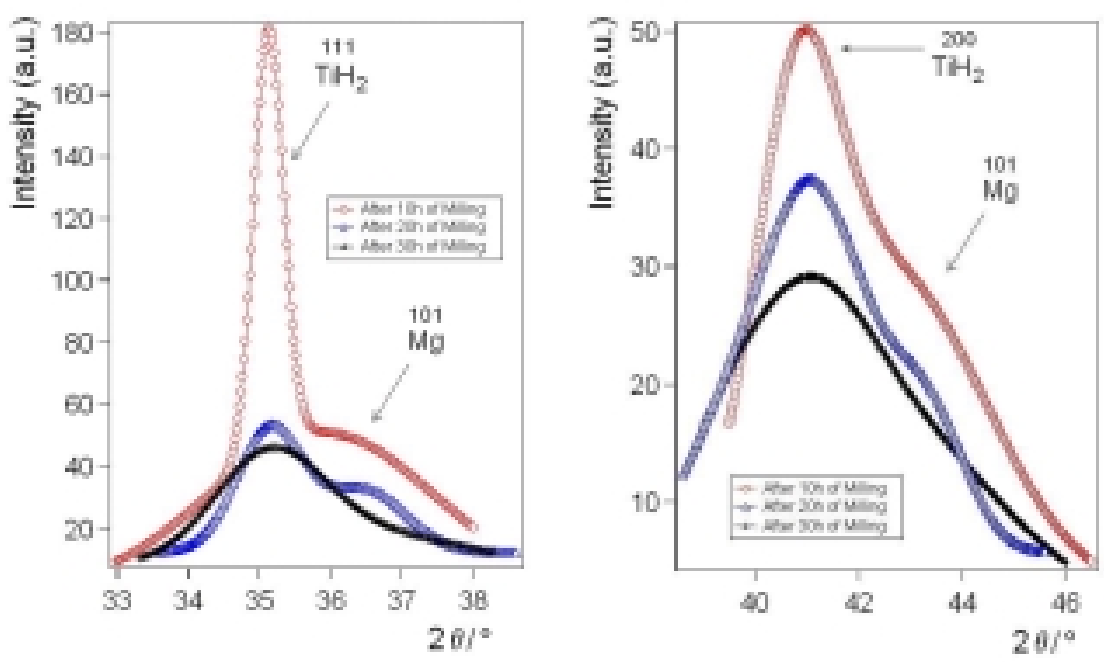

Figure 3. Normalization of Gaussian for $\mathrm{TiH}_{2}$ and $\mathrm{Mg}_{2} \mathrm{Ti}$ peaks.

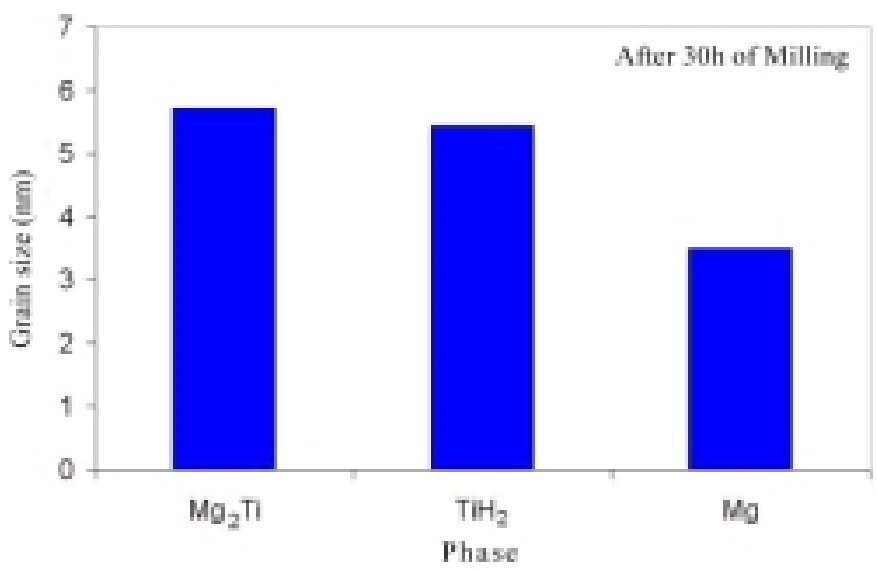

Figure 4. Crystallite sizes of $\mathrm{Mg}_{2} \mathrm{Ti}, \mathrm{TiH}_{2}$, and $\mathrm{Mg}$ phases calculated using Scherrer formula after $30 \mathrm{~h}$ of milling.

Figure 5 shows the XRD refinement result of the specimen after hydriding at $300{ }^{\circ} \mathrm{C}$. Three phases are observed, indicated as the $\mathrm{Mg}_{2} \mathrm{TiH}_{4}$, $\mathrm{TiH}_{2}$ and $\gamma-\mathrm{MgH}_{2}$ phases with the mass fractions of $25.48 \mathrm{wt} \% ; 64.0 \mathrm{wt} \%$; and $10.53 \mathrm{wt} \%$ respectively. The suggested reaction during the hydriding process is presented as follow:

$$
\mathrm{Mg}_{2} \mathrm{Ti}+\mathrm{TiH}_{2}+4 \mathrm{Mg}+\mathrm{Ti}+7 \mathrm{H}_{2} \rightarrow \mathrm{Mg}_{2} \mathrm{TiH}_{4}+2 \mathrm{TiH}_{2}+4 \mathrm{MgH}_{2}
$$




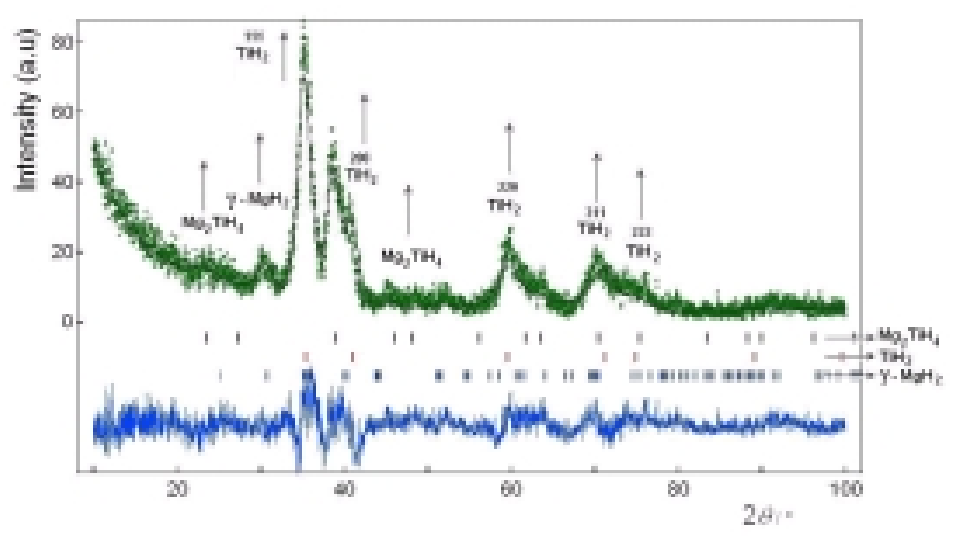

Figure 5. The XRD refinement result of the specimen after $30 \mathrm{~h}$ of milling.

The structure parameters and Wyckoff positions for the $\mathrm{Mg}_{2} \mathrm{TiH}_{4}$ and $\gamma-\mathrm{MgH}_{2}$ phases are presented in Table 3 below.

Table 3. The structure parameters and Wyckoff positions for $\mathrm{Mg}_{2} \mathrm{TiH}_{4}$ and $\gamma-\mathrm{MgH}_{2}$ phases.

\begin{tabular}{|c|c|c|c|c|c|c|c|c|c|}
\hline \multicolumn{5}{|c|}{$\begin{array}{c}\mathrm{Mg}_{2} \mathrm{TiH}_{4} \text { phase (ref. Genossar } \\
{[18] \text { ) }}\end{array}$} & \multicolumn{5}{|c|}{$\gamma-\mathrm{MgH}_{2}$ phase (ref. Bastide [19]) } \\
\hline \multicolumn{5}{|c|}{$\begin{array}{l}\text { Space group : F43m } \\
\text { Crystal structure : cubic } \\
\text { Lattice parameters : } \\
a=b=c=6.525 \AA\end{array}$} & \multicolumn{5}{|c|}{$\begin{array}{l}\text { Space group : Pbcn (60) } \\
\text { Crystal structure : Orthorhombic } \\
\text { Lattice parameters : } \\
\begin{array}{l}a=5.09(4) \AA, \quad b=4.98(6) \AA \text { and } c \\
=5.046(1) \AA\end{array}\end{array}$} \\
\hline Atom & Occ & $x$ & $y$ & $z$ & Atom & Occ & $x$ & $y$ & $z$ \\
\hline $\mathrm{Ti}$ & 1.0 & 0.0 & 0.0 & 0.0 & $\mathrm{Mg}$ & 1 & 0. & $0.259(1)$ & 0.25 \\
\hline $\mathrm{Mg}$ & 1.0 & 0.25 & 0.25 & 0.25 & $\mathrm{H}$ & 1.0 & $0.334(2)$ & $0.455(1)$ & $0.512(2)$ \\
\hline $\mathrm{H}$ & 0.5 & 0.516 & 0.516 & 0.516 & & & & & \\
\hline
\end{tabular}

Figure 6 shows the growth of new phases during the hydriding process. Before hydriding, the peaks identified as $\mathrm{TiH}_{2}$ phase in the plane (111) are quite low (after $30 \mathrm{~h}$ of milling). After hydriding the peaks of the $\mathrm{TiH}_{2}$ phase intensify. In addition, new phases are found at $2 \theta$ of about $31^{\circ}$ and $39^{\circ}$. These phases are identified as $\gamma-\mathrm{MgH}_{2}$ phase in the (111) plane and $\mathrm{Mg}_{2} \mathrm{TiH}_{4}$ phase in the (220) plane. The growth of the $\mathrm{TiH}_{2}$ peaks and new peaks identified as the $\gamma-\mathrm{MgH}_{2}$ and $\mathrm{Mg}_{2} \mathrm{TiH}_{4}$ support the view that the longer milling time will result in the higher the hydrogen capacity of the specimen. 


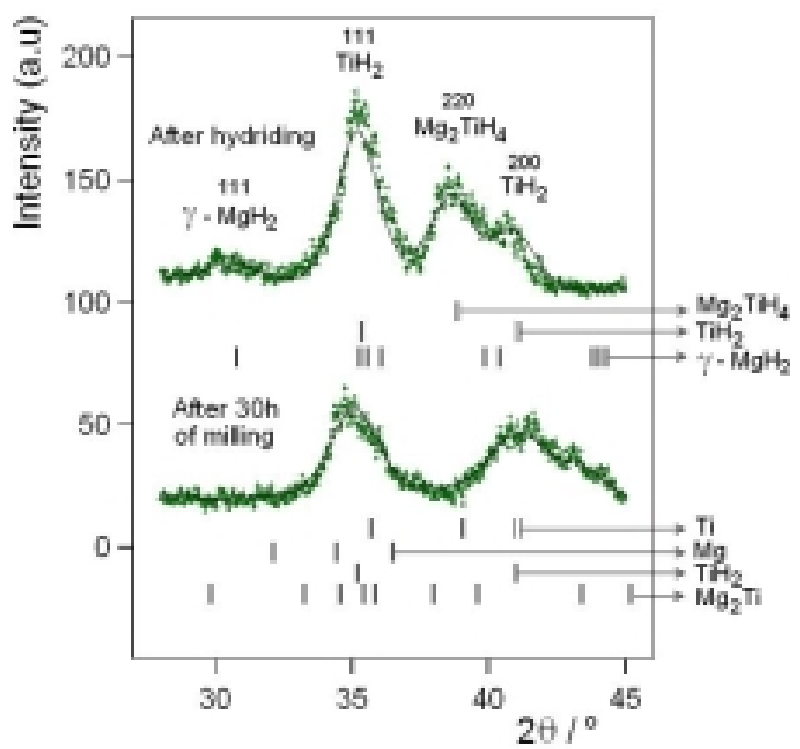

Figure 6. Phase identification of the specimen before and after hydriding process.

Figure 7 depicts the morphology of the specimens before and after the hydriding process. Before hydriding, the crystallites are in a polygonal form. After hydriding, the particle shape change into an irregular one [20], an indication that diffusion of particle occurs and new phases are formed. As previously indicated by the XRD analyses, new phases of $\mathrm{Mg}_{2} \mathrm{TiH}_{4}, \mathrm{TiH}_{2}$ and $\gamma-\mathrm{MgH}_{2}$ are grown.

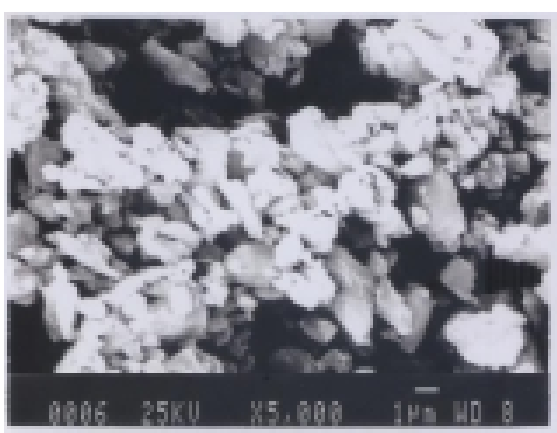

(a) After $30 \mathrm{~h}$ of milling.

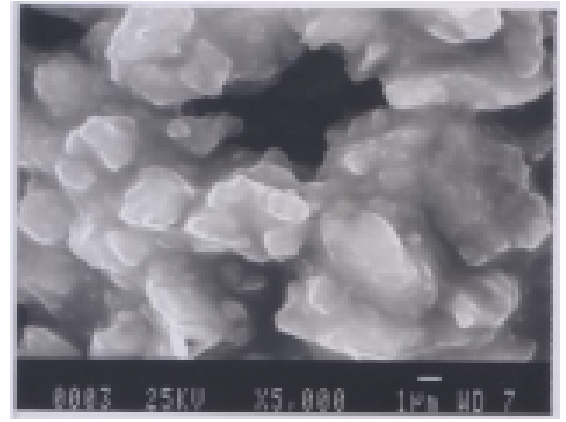

(b) After hydriding at $300{ }^{\circ} \mathrm{C}$.

Figure 7. Morphology of the specimens for (a) Mg-Ti-H after milling and (b) Mg-Ti-H after hydriding. 


\section{CONCLUSION}

The synthesis and characterization of the Mg-Ti and Mg-Ti-H alloys have been carried out in order to investigate the possibility to be used as a hydrogen storage materials. The XRD refinement results of the Mg-Ti specimens show that mechanical alloying of the $\mathrm{Mg}$ - $\mathrm{Ti}$ powders under toluene solution results in the formation of the $\mathrm{Mg}$, $\mathrm{Ti}, \mathrm{TiH}_{2}$ and $\mathrm{Mg}_{2} \mathrm{Ti}$ phases. The formation of $\mathrm{TiH}_{2}$ in the specimen disturbs the growth of binary the $\mathrm{Mg}_{2} \mathrm{Ti}$ compound. After $30 \mathrm{~h}$ of milling the mass fractions of the $\mathrm{Mg}$, Ti, $\mathrm{TiH}_{2}$ and $\mathrm{Mg}_{2} \mathrm{Ti}$ phases are $5.26 \mathrm{tw} \%, 1.25 \mathrm{wt} \%, 62.90 \mathrm{wt} \%$ and $30.60 \mathrm{wt} \%$ respectively. After hydriding at $300{ }^{\circ} \mathrm{C}$, the specimen is transformed into $\mathrm{Mg}_{2} \mathrm{TiH}_{4}, \mathrm{TiH}_{2}$ and $\gamma-\mathrm{MgH}_{2}$ phases with mass the fraction of $25.48 \mathrm{wt} \%$, $64.0 \mathrm{wt} \%$, and $10.53 \mathrm{wt} \%$. The growth of the $\mathrm{TiH}_{2}$ peaks and the formation of new peaks the $\gamma-\mathrm{MgH}_{2}$ and $\mathrm{Mg}_{2} \mathrm{TiH}_{4}$ support the view that the longer milling time will result in the higher the hydrogen capacity of the specimen. Microstructure analyses reveal that due to the diffusion process, the particles of the specimen change from polygonal shape into irregular one. To be promoted as a hydrogen storage material, further examination on the $\mathrm{Mg}-\mathrm{Ti}$ alloy is being conducted in the form of hydrogen capacity measurements and hydriding-dehydriding properties.

\section{ACKNOWLEDGEMENT}

The Authors would like to express their gratitude to the State Minister of Research and Technology for provisioning financial support through the Incentive Program, KNRT, fiscal year 2008; PT. BATAN Teknologi for providing facilities and supports for this research program; the Director of the Center for Technology of Nuclear Fuel, BATAN; and the Director of the Center for Technology of Nuclear Industry Material, BATAN.

\section{REFERENCES}

1. BOBET, J.L., CHEVALIER, B., DARRIET, B., J. Alloys Comp., 738, 330-332, 738-743 (2002).

2. IMAMURA, H., TAKESUE, Y., AKIMOTO, T., TABATA, S., J. Alloys Comp., 293-295, 564-568 (1999).

3. TAKAMURA, H., MIYASHITA, T., KANEGAWA, A. OKADA, M., J. Alloys Comps., 356-357, 804-808 (2003).

4. CRIVELlO, J.C., NOBUKI, T., KATO, S., ABE, M., KUJI, T., J. Advanced Science, 19, 88-96 (2007).

5. BOUARICHA, S., DODELET, J.P., GUAY, D., HUOT, J., BOILY, S., SCHULZ, R., J. Alloy Comp., 297, 282-293 (2000). 
6. ARNASON, B., SIGFUSSON, T.I., Int. J. Hydrogen Energy, 25, 389-394 (2000).

7. LIANG, G., HUOT, J. BOILY, S., NESTE, A.V., SSHUlTZ, R., J. Alloys Comp., 348, 319-324 (2003).

8. ROUSSElOT, S., BICHAT, M.-P., GUAY, D., ROU'E'e, L., J. Power Sources, 175, 621-624 (2008).

9. HARRIS, J.R., :"Matemathical Modelling of Mechanical Alloying", Thesis submitted to The University of Nottingham for the degree of Doctor of Physlosophy, Sepetember (2002).

10. ZALUSKA, A., ZALUSKI, L., STROM-OLSEN, J.O., J. Alloys Comp., 228, 217-225 (1999).

11. KONDO, T., SHINDO, K., SAKURAI, Y., J. Alloys Comp., , 386, 202-206 (2005).

12. SUWARNO, H., WISNU, A.A., ANDON, I., Int'l Conf Solid State Ionic, Proc, PTBIN, Serpong, Indonesia (2007).

13. IZUMI, F., Rietan Manual, 1994 (private communication).

14. SWANSON, T., JC Fe Reports, NBS, Natl. Bur. Stand. Report, (1951).

15. SAILER, R., MC CARTHY, G., North Dakota State University, North Dakota, USA, ICDD Grand in Aid, (1993).

16. CRANE, R.L., CHATTORAJ, S.C., STROPE, M.B., J. Less-Common Met., 25, 225-227 (1971).

17. SOUBEYROUX, J.L., FRUCHART, D., MIKOU, A., PEZAT, M., DARRIET, B., et al., Mater. Res. Bull., 19, $895-904$ (1984).

18. GENOSSAR, J., RUDMAN, J., Phys., Chem. Solid, 42, 611 (1981).

19. BASTIDE, J.P., BONNETOT, B., LETOFFE, J.M., CLAUDY, P., Mater. Res. Bull., 15, 1779-1787 (1980).

20. GERMAN, M. R., :'Powder Metallurgy Science, second edition", Metal Powder Industries Federation, New Jersey (1994). 